\title{
THE ROLE OF EFFICIENCY AS MEDIATOR FOR THE INFLUENCE OF FIRM SIZE ON FINANCIAL PERFORMANCE OF BANKING THAT DO MERGER AND ACQUISITION IN INDONESIA
}

\author{
Purbosanjoyo Pryobudi, Moeljadi, Djazuli Atim, Wijayanti Risna \\ Department of Management, Faculty of Economics and Business, \\ University of Brawijaya, Indonesia \\ *E-mail: prybudip@yahoo.com
}

\begin{abstract}
Banking in Indonesia has experienced a difficult period since the financial crisis in 1997 that directly or indirectly affected the banking sector. Many private banks have to be liquidated. The banking industry has decreased and stagnated due to many problems, such as decreased profitability, lack of capital and non-performing loans. National banks consolidate to improve financial performance, one of the ways to do is to merge and acquire. This study aims to test and prove empirically banks that do mergers and acquisitions: (1) Does firm size directly affect the efficiency and financial performance. (2) Whether efficiency directly affects financial performance (3) Does firm size indirectly affect financial performance mediated by efficiency. Theoretically, the result of this research is expected to enrich and complete the repertoire of science in the field of management science, especially the theory of financial management of banking, so it can be useful for academics and practitioners. The number of commercial banks in Indonesia reached 118 banks. The population of this research is commercial banks that merged and acquired post-1997 economic crisis until 2010 . The sample of the study was taken from all banks that merged and acquired as many as 14 banks. Sampling using saturated sampling method (census). The design of this research using explanatory approach. Data analysis method used in hypothesis testing is path analysis and using Structural Equation Model analysis tool with WarpPLS 5.0 program. The results of this research indicate that: (1) The firm size directly affects the efficiency, but does not directly affect the financial performance. (2) efficiency directly affects financial performance. (3) The firm size indirectly affect the financial performance is mediated by efficiency. The conclusion of this research is efficiency has a dominant role to improve financial performance, while the novelty of this research is entering efficiency as mediation for influence of firm size to financial performance of banking that do merger and acquisition.
\end{abstract}

\section{KEY WORDS}

Firm size, efficiency, finance, performance.

Banking in Indonesia has been growing rapidly since the issuance of the government's policy in 1988, among others, in the form of relaxation of capital provisions for the establishment of new banks has led to the emergence of a number of small and mediumscale commercial banks with the addition of new branches. The number of commercial banks in Indonesia swelled from 111 banks in 1988 to 222 banks before the 1997 economic crisis. Banks experienced intense competition, the number of banks making the competition for job search, the mobilization of deposit and savings funds, was also increasingly fierce. Banks continue to be encouraged to seek profit so that the principle of prudential banking in the disbursement of funds is neglected and ultimately problematic loans mounting amount.

National banking has experienced a difficult period since the 1997 financial crisis that directly or indirectly affected the banking sector. Many private banks have to be liquidated. In view of Mulyaningsih and Daly (2011) that the 1997 financial crisis caused distress in the national banking industry and has been ongoing for so long that banks have decreased and stagnated due to many problems including decreased profitability, lack of capital and nonperforming loans. In order to restore public confidence in the national banking system, the government at that time issued various policies to reorganize the national banks, among 
others, establishing the Indonesian Bank Restructuring Agency and recapitalizing the national banking system. National banks are restructuring to improve their financial performance. Banks must raise capital to achieve business scale by increasing the capital contribution from shareholders or merging capital from the merger. Larger capital allows banks to sustain businesses and risks and develop technology and increase lending capacity. Banks are allowed to receive additional capital from old owners, merge or be acquired by a larger bank, or sell shares in the capital market.

The banking industry in Indonesia is revamping to support the consolidation process in the banking sector through mergers and acquisitions ( $M \& A)$. The priority is to enlarge the size of the firm with the aim of obtaining the economies of scale from the joining banks. To achieve these objectives banks must be able to provide and sell efficient and quality banking products and services. In the era of highly competitive banking business, the banking competition climate is characterized by increasingly sophisticated customers to demand quality products and services at an efficient rate. Banking relies on its business on the sale of efficient and quality banking products and services to meet customer demands. Efficiency can be obtained in various ways, in this study with the larger size of the firm due to the $M$ \& $A$ process, it is expected the firm can improve the efficiency and financial performance.

Consolidation of banks through $M \& A$ in Indonesia has increased the distribution of market share as many banks are engaged in the same segment. This is because $M \& A$ is done in the market of medium and small banks aiming to improve financial performance after the 1997 financial crisis or to adjust to the policy of single presence and minimum capital requirement. This consolidation increases the economies of the banks that join, but does not increase the concentration of the industry because mergers are dominated by small and medium-sized banks (Mulyaningsih \& Daly, 2011). This condition resulted the banking in Indonesia not concentrated to certain segments, so the size of the firm is expected to be a factor that can improve efficiency and financial performance. Therefore, the banking authorities support consolidation through $M$ \& $A$ in order to create a strong, healthy and efficient banking structure.

The synergy that occurs from banks that join through $M \& A$ is the key to success in an effort to create efficiency and financial performance. The financial performance of banks performing M \& A during the period 2010 - 2014 shows the average tends to decline. Factors affecting the decline in financial performance are profit before tax and firm size. Average earnings before taxes show an increasing trend, as well as the size of the firm is the total assets owned by banks is increasing significantly. Nevertheless, the average increase in firm size is greater than the average increase in profit before tax, so this resulted in financial performance tends to decline.

This study aims to determine the influence of banks that do $M \& A$ on efficiency and financial performance, either directly or mediated by efficiency. Implementation of $M \& A$ in this study is proxied by firm size. Firm size is a quantitative type of data in the form of ratios in which this important factor is suspected to have an effect on efficiency improvement and lead to improved financial performance. The problem in this research is how the influence of firm size to the efficiency and financial performance of banking that do $M$ \& $A$ in Indonesia, either directly or mediated by efficiency. The selection of banks conducting $M \& A$ in this study with the consideration that banks do $M$ \& A make it possible to benefit from new business opportunities that have been made by changes in regulation and technology. According to the results of Epstein research (2005) states that banks have implemented business strategy by doing $M$ \& $A$ offers new opportunities for increased efficiency and performance of banks. To explore the problem further, then an assessment of the results of previous studies relevant to the problem.

The results of previous studies on non $M \& A$ banks show that the size of the larger firms, it will have an impact with increasing financial performance (Alexiou \& Sofoklis, 2009; Gul et al., 2011; Naseem et al., 2012; Doğan, 2013; Bilal et al., 2013; Menicucci \& Paolucci, 2016; Dewi et al., 2016). While the results of research from Pasiouras and Kosmidou (2007); Dietrich and Wanzenried (2009); Sufian and Habibullah (2009); Javaid et al. (2011) found that the larger the size of the firm can degrade financial performance. Similarly, the findings 
of Athanasoglou et al. (2006); Ali et al. (2011); Said and Tumin (2011); Prasanjaya and Ramantha (2013); Lelissa, T.B. (2014) found that firm size had no effect on financial performance.

The existence of contradictions or inconsistencies of previous research results on the effect of firm size on the efficiency and financial performance, this situation needs to be clarified through empirical studies by re-examining the effect of firm size on the efficiency and financial performance of banks conducting $M \& A$. In addition, this study aims to Investigating the role of efficiency as mediating the effect of firm size on financial performance. Thus, further research needs to be done, especially for banking companies that do $M$ \& $A$ in Indonesia. The motivation for this research is as follows: (1) There is a phenomenon of success, failure or obstacles in the implementation of firm size to improve efficiency and financial performance becomes important to do further research to answer the existing problems. (2) There are differences of previous research results on testing the effect of firm size on efficiency and financial performance, the difference is caused by the basic theory used, the object being studied and the diversity of measurement indicators. There is no clear consistency and concept of the measurement indicators of these variables, the basis for consideration to conduct re-testing by developing a measurement model that includes efficiency as a mediation that influence the size of the firm on financial performance.

Based on the problems faced by banks conducting M \& A in Indonesia, the debate and empirical gaps from previous research have attracted the attention of researchers to conduct this research. The main problem of this study is whether the size of the firm affect the efficiency and financial performance either directly or mediated by the efficiency of banks that do M \& A in Indonesia. Specifically, the problems of this study are: (1) Does the firm's size directly affect efficiency?; (2) Does the size of the firm directly affect the financial performance? (3) Does the size of the firm indirectly affect financial performance mediated by efficiency?.

The purpose of this study is to examine and explain the effect of firm size on the efficiency and financial performance either directly or mediated by the efficiency of the banking performing $M$ \& $A$. Theoretical contributions to the development of conceptual and theory insight about firm size and efficiency in relation to financial performance Banks that conduct $M$ \& $A$ in Indonesia based on banking financial management theory. Practical contributions are thought-provoking contributions to management and business actors in the banking industry that consolidate through $M$ \& $A$ using firm size in an effort to improve efficiency and effectiveness in banking operations.

\section{LITERATURE REVIEW}

Theoretical study is conducted as a foundation in order to study and measure the influence among variables in this study refers to the theory of financial management of banking, which is one of the main functions of banking. Then it is associated with the existence of strategic decisions in banking financial management that is the merger and acquisition in the national banking and how the influence on financial performance. To further focus the study in this study is the size of the firm as a proxy of $M$ \& $A$ in building theory as the basis of thinking empirically back to the philosophy of firm size with reference to the theory of synergy as a basic theory. To achieve that objective, theoretical study was conducted in testing and explaining the effect of firm size on efficiency and financial performance supported by the concept of firm size and efficiency, with the following rationale and understanding.

Firm size. Theoretical study used as the basis for the measurement and testing of relationships among variables in this study is the theory of firm size. Firm size describes the size of a firm that can be judged by total assets owned, total sales, average total sales and average assets. The firm has grown to gain economies of scale that is reflected in a decrease in operating costs (input) in line with an increase in operating income (output). The use of the concept of firm size in this study with a contingency perspective can test and explain the effect of firm size on efficiency and financial performance. The concept of firm 
size becomes the foundation on measuring and testing the effect of firm size on efficiency and financial performance. In general large firms have large total assets capable of generating large profits. Large firms have a distinctive appeal to consumers because large firms tend to have less bankruptcy risk as the number of assets tends to be large. So the size of the firm can be seen from the size of the capital and total assets owned. The indicator of firm size is the total assets of total assets owned by the firm (William, 2000; Menicucci \& Paolucci, 2016). Firm size is measured by the natural logarithm of total assets (Naiker et al., 2008), which shows the growth of firm assets.

Efficiency. The theory relating to efficiency refers to the difference between the observed value and the optimal value of the input, output and input / output combination (Bikker and Bos, 2008). Efficiency can be defined as the ratio between output and input (Kost \& Rosenwig, 1979 in Sutawijaya \& Lestari, 2009). There are three factors that link efficiency: (1) if the same input produces a larger output; (2) smaller inputs produce the same output; (3) large inputs produce larger outputs. When viewed from economic theory, there are two meanings of efficiency, namely: (1) technical efficiency (micro perspective); (2) economic efficiency (macro point of view). Measurement of technical efficiency tends to be limited to technical and operational relationships in the process of converting inputs into outputs. According to Ayadi and Pujals (2005) that M \& A allows companies to derive efficiency gains generated through cost reduction or cost synergies, increased revenues or revenue synergies, best practice exchange and / or risk diversification. Cost synergies result from an improved organization for the banking services industry, better scale and / or better combination of production factors. Cost synergy can come from the integration of different expert teams or information technology infrastructure and comes from different combinations of back-office and general corporate services. While income synergy comes from a better combination of production factors such as product harmonization, complementary existing cross-selling, and generalization of the multi-distribution channel approach to different customer segments. Income synergies are much more difficult to obtain than cost synergies, because they depend not only on managers' decisions but also on customer behavior.

The efficiency gains obtained by adjusting inputs and outputs in order to reduce costs, increase revenue and / or reduce risk so as to increase the value. Companies engaged in banking can perform the efficiency of the operation is to determine whether the bank in its operations related to the principal business of the bank, done correctly in the sense in accordance with management expectations and shareholders (Hanley, 1997 in Sudiyatno \& Suroso, 2010). Operating efficiency can affect financial performance that is to show whether the bank has been using all factors of production efficiently and effectively. Given that the bank's main activity is to act as a financial intermediary, collecting funds and channeling public funds, the costs and operating income of banks are dominated by interest and interest costs. Efficiency comes from a variety of different activities undertaken by the company in running the company's operating activities. The efficiency analysis is based on the indicator in the Income Statement by measuring the cost to income ratio by checking the total Operating Cost (non interest expense and interest expense) to total Operating Income referred to as BOPO. The company's success in managing efficiency directly affects the company's rentability because any increase in operating costs will result in a decrease in profit before tax and will ultimately lower the profit or profitability of the company. Enterprise efficiency can be achieved in various ways, in this study using firm size. Theory of efficiency is used as a basis in measuring the efficiency of the company which ultimately leads to the financial performance of the banking system. The efficiency of the Bank becomes very important in explaining and interpreting bank performance (Molyneux et al., 1997 in Bikker \& Boss, 2008).

The efficiency ratios used in this study refers to the financial ratios used by Holkas and Salamouris (2004) in Putri and Lukviarman (2008) and Christian et al. (2008) in Mathuva (2009). BOPO is an operating cost ratio used to measure the level of efficiency and ability of banks in conducting operations. BOPO's increasing ratio reflects the lack of ability of banks to reduce operating costs that can cause losses because banks are less efficient in managing the business. BOPO ratio is often called the efficiency ratio is used to measure the 
ability of bank management in controlling operating costs to operating income. Considering that the principal activities of the bank in principle are to act as an intermediary to collect and channel public funds, the costs and operating income of the bank are dominated by interest and interest (Dendawijaya, 2005). Operating costs are calculated based on the sum of the total interest expense and other total operating expenses. Operating income is the sum of total interest income and total other operating income. The smaller the ratio of BOPO means the more efficient the operating costs incurred by the bank concerned. Similarly, the greater the ratio BOPO means the less efficient operating costs incurred by the bank concerned that makes profits decreased. The bank's success is based on a quantitative assessment of bank profitability that can be measured using the ratio of operating costs to operating income (Kuncoro \& Suhardjono, 2002). This is due to any increase in operating costs will result in a decrease in profit before taxes and will eventually reduce the profit or profitability of the bank concerned.

The concept of efficiency as a variable of mediation (intervening) between firm size and financial performance is to determine indirect effect of firm size as independent variable to financial performance as dependent variable. In this study the efficiency of the company is proxied by the ratio of BOPO which serves as the intervening variable of the relationship between firm size and financial performance. The smaller the percentage ratio of BOPO the better the level of efficiency of the company, otherwise the greater the percentage ratio of BOPO then the less good level of efficiency of the company.

Financial Performance. Theory of banking performance according to Bikker and Bos (2008) is the basic model of banking performance for profit maximization based on the key assumptions in the literature that the bank as a profit maker with the consideration to: (1) the concept of risk and diversification; (2) Reward structure; (3) Market forces; (4) Efficiency. Bank performance is achieved by maximization of profit (profit maximization), namely the ability of banks to maximize revenue and minimize costs (Bikker \& Boss, 2008). According to economic theory in perfect competition situation, profit maximization is equivalent with minimization of cost. A bank can operate at a lower cost and with higher profits compared to other banks if the bank is better at using inputs and converting them into outputs as cheaply as possible. The purpose of a company is established in general is to achieve a value is high, where to achieve the value the company must be able to efficiently and effectively in managing various activities. One measure to find out how far the efficiency and effectiveness achieved is to see the profitability of the company, the higher the profitability then the more effective and efficient management of corporate activities.

The size of bank profitability can be seen from various ratios, such as Return on Assets (ROA), Return on Equity (ROE) and Net Profit Margin (NPM). In this study the variables used as the dependent variable is bank profitability in this case serves as a financial performance to explain the effect of firm size on financial performance either directly or mediated by efficiency. Profitability measure used in this research is ROA as dependent variable. ROA shows the profit earned per Dollar / Rupiah asset and most importantly reflects the ability of management to utilize bank finance and real investment resources to generate profits (Hassan \& Bashir, 2003 in Sufian \& Habibullah, 2010). ROA for banking depends on bank policy decisions such as uncontrollable factors related to economic and government regulations. Rivard and Thomas (1997) in Sufian and Habibullah (2010) suggest that bank profitability uses best measurements with ROA given that ROA is not distorted by high equity multipliers and is a better measure of the firm's ability to generate returns from asset portfolios. ROA is a good overall indicator of the performance of banking organizations that describes the ability of banks to generate profits from the assets used. The greater the percentage of ROA the better the company's ability to generate profits from the assets used, otherwise the smaller the percentage of ROA, the smaller the company's ability to generate profits from the assets used.

Profitability ratio is considered as the most valid tool in measuring the results of the implementation of the company's operations, because the ratio of profitability is a comparison tool on various investment alternatives in accordance with the level of risk. The greater the risk of investment, expected profitability obtained higher also. Profitability is a specific 
measure of a bank's performance, which is the goal of corporate management by maximizing shareholder value, optimizing returns, and minimizing risks. The purpose of profitability analysis of a bank is to measure the level of business efficiency and profitability achieved by the bank concerned (Kuncoro \& Suhardjono, 2002). The company's financial performance from the management side, expect high net profit before tax because the higher the company's profit the company's more flexible in running the company's operations. So that the Earning Before Tax (EBT) of the company will increase when the company's financial performance increases. Profit before tax is net income from pre-tax operating activities. While the average total assets is the average volume of business or assets (Dendawijaya, 2005). Achievement of profit is a dominant indicator because the end result of business operations performance always leads to EBT. Because EBT is the value of rupiah and each company is different in amount of capital then big EBT can not show profit performance so need to be used another indicator, in this research indicator from financial performance of banking is profitability company in this matter proxied by Return on Asset (ROA ) that functions as a dependent variable. ROA is one of the profitability ratios used to measure the effectiveness of a company in generating profits by utilizing its total assets, and ROA is a very important factor in assessing the financial performance of banks. Under the terms of Bank Indonesia, the good ROA standard is about 1.5\%. The greater the ROA shows the company's performance the better, because the greater the return.

\section{CONCEPTUAL FRAMEWORK}

This conceptual framework describes the relationship between research variables. The relationship between research variables is based on firm size theory, efficiency theory and financial performance theory and research results related to the effect of firm size on efficiency and financial performance, and to explain the role of efficiency as mediator for the influence of firm size on financial performance. Based on the relationship between the variables based on the theory and previous research, the conceptual framework of the research is as follows:

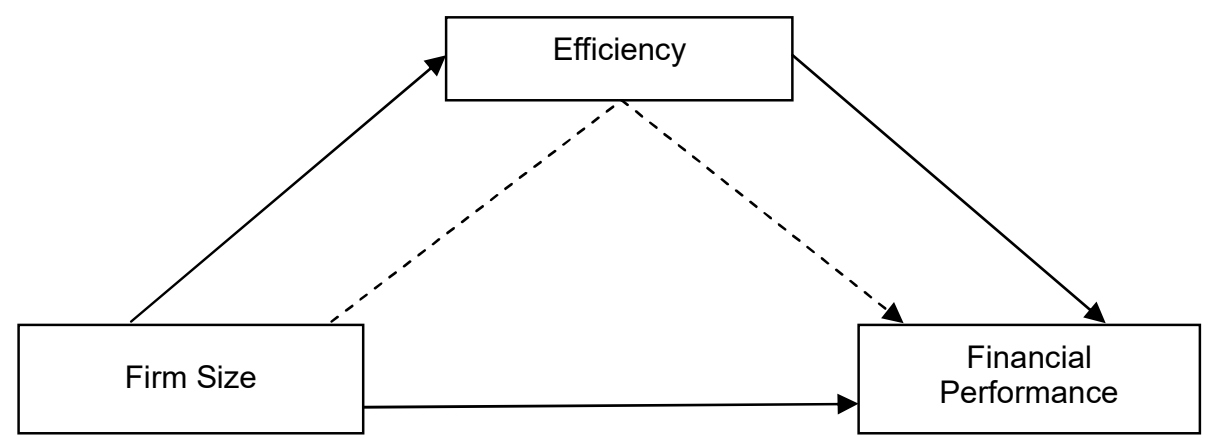

Note:

Direct Influence

Indirect Influence

Figure 1 - Research Conceptual Framework

The research hypothesesю Previous research has shown that firm size can indeed improve efficiency (Casu \& Molyneux, 2003; Havrylchyk, 2006; Fumony, 2012; Subandi \& Gozali, 2014) and has a significant effect on financial performance (Alexiou \& Sofoklis, 2009; Gul et al., 2011; Naseem et al., 2012; Doğan, 2013; Bilal et al., 2013; Dewi et al., 2016; Menicucci \& Paolucci, 2016). This is different from the findings of Girardone et al. (2004); Miah and Sharmeen, (2015) that firm size has no effect on efficiency and has no effect on financial performance (Athanasoglou et al., 2006; Prasanjaya \& Ramantha, 2013; Lelissa, TB, 2014). Firm size is only explained as a reaction that arises as a result of uncertainty. The majority of empirical studies are limited to the total size of the firm's assets. They rarely explore economies of scale from a firm-size perspective and are not yet involved in the $M \& A$ 
process. Therefore, this study develops a conceptual framework of firm size by exploring the production process and investing in the physical capital required to produce output by considering the quality of productive assets will generate revenue for banks, in order to support efficiency and financial performance. If the production function is assumed to be technological development, the output may increase (Kumar et al., 2001), as well as the business activities of the banking system both in terms of the use of funds and sources of funds that is reflected in the decrease in operating costs in line with the increase in operating revenues, which produces bigger outputs. Based on research objectives and study on conceptual framework of research, hence formulated hypothesis as follows:

$\mathrm{H} 1$ : The larger the size of the firm the higher the efficiency;

$\mathrm{H} 2$ : The larger the size of the firm the higher the financial performance.

Previous research has shown that efficiency can indeed improve financial performance (Sukarno \& Syaichu, 2006; Alexiou \& Sofoklis, 2009; Dietrich \& Wanzenried, 2009; Sufian \& Habibullah, 2009; Sudiyatno \& Suroso, 2010; Purwoko \& Sudiyatno; 2013; Prasanjaya \& Ramantha, 2013; Margaretha \& Zai, 2013; Dewi et al., 2016), but this is different from the findings of Widati, (2012); Sabir et al., (2013); Tan, (2013); Fajar et al., (2013) that efficiency has no effect on financial performance. Differences of empirical research results on the effect of efficiency on financial performance can be perceived that the difference is due to the diversity of indicators in the measurement, the object under study and the basic theory used. The inconsistencies of previous research findings provide an opportunity to re-examine the relationship between efficiency and financial performance. Based on research objectives and study on conceptual framework of research, hence formulated hypothesis as follows:

$\mathrm{H} 3$ : The higher the efficiency the higher the financial performance.

The company has grown to gain economies of scale that is reflected in the decline in operating costs in line with the increase in operating revenues. When this economic scale is achieved, which is expected to increase efficiency and in turn can support financial performance. Implementation of firm size with a contingency perspective can be used as a test and to gain insight into the effect of firm size on efficiency and financial performance at different levels of critical contingency variables. The results of previous research indicate that firm size has no effect on financial performance (Athanasoglou et al., 2006; Said \& Tumin, 2011; Ali et al., 2011; Prasanjaya \& Ramantha, 2013; Lelissa, TB, 2014), and therefore the concept should be expanded through the effect of efficiency on financial performance. Firm size should be seen as a key determinant for improving financial performance through efficiency. For the long term, firm size can be used to improve financial performance and should impact on corporate profits or overall financial performance. Based on research objectives and study on conceptual framework of research, hence formulated hypothesis as follows:

H4: The larger the size of the company the higher the financial performance mediated by efficiency.

\section{METHODS OF RESEARCH}

The design of this research using explanatory research approach with the aim of making clear the relationship between variables through hypothesis testing and make a causal conclusion and then followed by choosing between alternative actions. The reason for the use of explanatory research design is because the purpose of this study is to prove empirically and explain the effect of firm size on the efficiency and financial performance of banking performing $M \& A$. Unit of analysis in this study is a company in the banking industry in Indonesia which reached 118 banks. Target population or sample of research are banks that conduct $M$ \& A with government or private ownership and head office in Jakarta. All banks in the target population are observed (saturated samples). The sampling technique used is saturated sampling (census) because the population is relatively small and managed by researchers, ie 14 companies. The selection of population as well as samples with census in this study is the banks in Indonesia who do M \& A post 1997 economic crisis.

Methods of data collection used in this study is First, the literature review is done to 
assess the theory or the results of previous research, relevant to the steps used in this study. Secondly, secondary data of a banking company is a publication financial report that can be downloaded from the website of the Financial Services Authority and Bank Indonesia and the bank's annual report. Secondary data used in this research is panel data that is in the form of cross-sectional and time series in the period of 5 years, that is year $2010-2014$. Third, primary data by conducting interview and or disseminating questionnaire directly to parties concerned by bank-bank post M \& A with the main focus of the board of directors of the banks.

The variables studied with indicator as measurement are as follows:

Table 1 - Research variables

\begin{tabular}{|c|c|c|c|}
\hline No. & Variables & Indicators & Formula \\
\hline 1. & Firm size (size) & Total Asset & Size $=$ Ln (Total Asset) \\
\hline & & Operating Cost & Operating Cost \\
\hline 2. & Efficiency (Effi.) & Operating Income & $\begin{array}{c}\text { Effi. = --------------------- X 100\% } \\
\text { Operating Income }\end{array}$ \\
\hline 3. & Financial Performance (Perf.) & $\begin{array}{c}\text { Earning Before Tax } \\
\text { Total Assets }\end{array}$ & 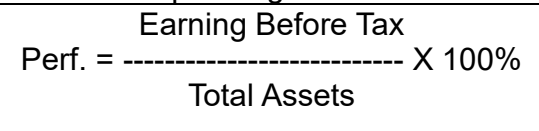 \\
\hline
\end{tabular}

Data analysis methods used to answer the formulation of the problem in this research is Path Analysis method used to analyze the patterns of relationships among the variables with the aim to determine the direct or indirect influence of the independent variables to the dependent variables. The collected data were analyzed using the variant-based Structural Equation Modeling (SEM) method known as Partial Least Square (PLS). Two stages of SEMPLS analysis are used sequentially in evaluating the research model, i.e. testing of outer model and inner model testing. Outer model (measurement model) is an assessment of the reliability and validity of research variables. While testing the structural model (inner model) is done to determine the relationship between constructs and the relationship between independent variables and dependent variables, the hypothesis can be analyzed. In this research, SEM test analysis with WarpPLS 5.0 program was used to find out the correlation between firm size (Size), efficiency (Effi) and financial performance (Perf), while the measurement or test of significance at the level of $1 \%$ or $p$-value $<0.001$ is a measure of the probability of strength of evidence to reject or accept the null hypothesis $\left(\mathrm{H}_{0}\right)$.

\section{RESULTS OF STUDY}

Data analyzed using Path Analysis is used to analyze relationship pattern between variables with the aim to know the direct or indirect effect of a set of independent variables to the dependent variable. Hypothesis test in this research uses SEM analysis tool with WarpPLS 5.0 program. This analytical tool was chosen because there are several advantages that are designed to solve problems such as small sample size, multivariate nondistributed data, missing values and multicololinearity problems among exogenous variables (Ghozali \& Latan 2014). The following test results of fit and quality indice models are as follows:

Based on the results of testing on the fit and quality indices model above that: the average path coefficient (APC) has a quality index of 0.470 with $p$-value $<0.001$; the verage $R$ Squared (ARS) has a quality index of 0.551 with $p$-value $<0.001$. Both quality indexes show results below p-value $<0.01$ which means APC and ARS have a good fit model. Likewise, the Average Variance Inflation Factor (AVIF) produced is $1.184<5$, meaning that the model is correct or acceptable. The model fits with the data so that the model can be used to perform the following test.

The result of statistical test shows that the value of $r$-square for Efficiency variable (Effi.) of 0.15 which means that the effect of the firm size (size) to the efficiency is $15 \%$; the rest $85 \%$ is influenced by other factors outside the research model, while the effect of firm 
size on the financial performance through efficiency is equal to 0.95 or $95 \%$; the remaining $5 \%$ is influenced by other factors outside this research model.

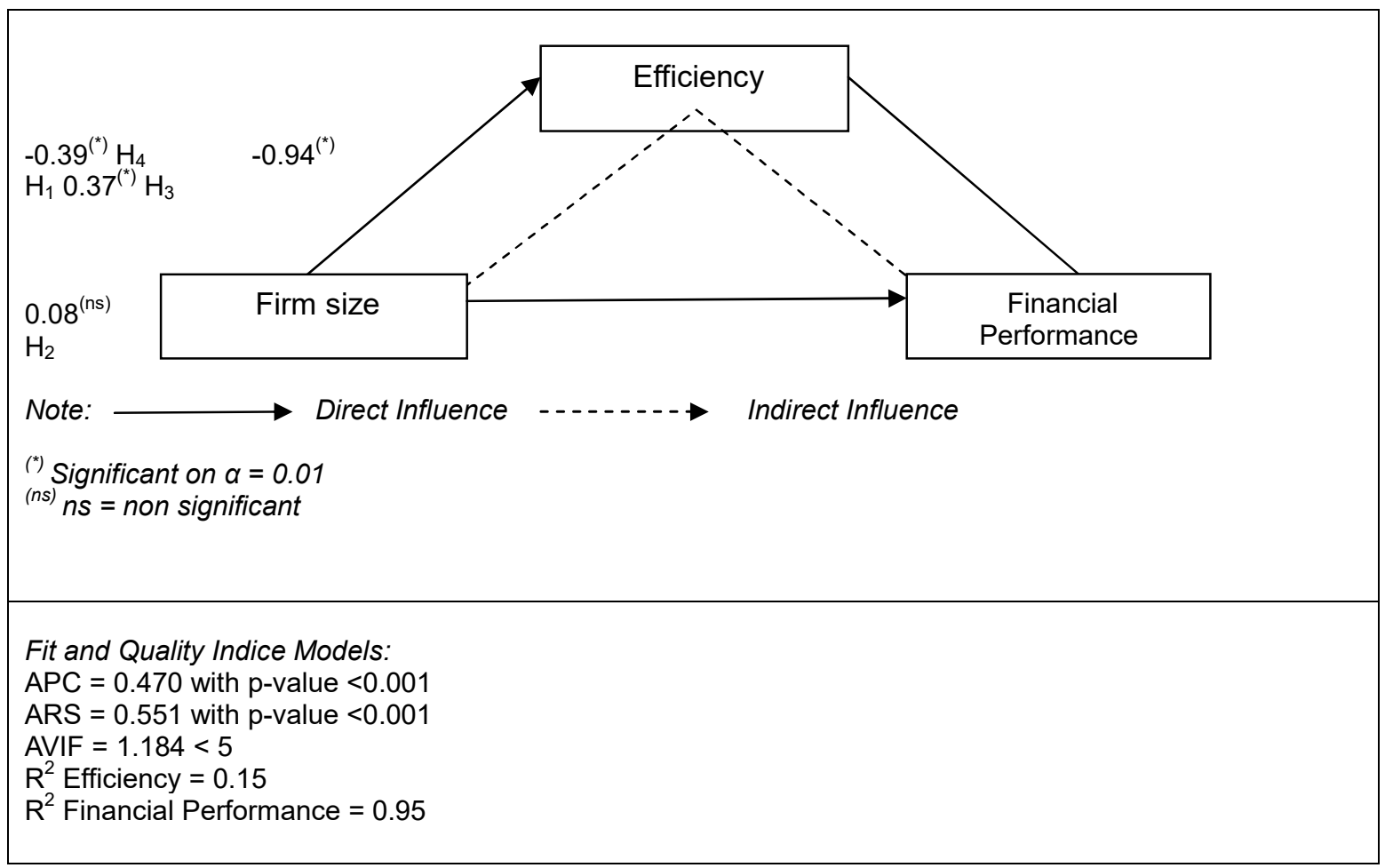

Figure 2 - Diagram for Hypothesis Testing and Path Coefficient

The results of hypothesis testing and path coefficient as presented in Table 2 are as follows: (a) the indirect effect of the firm size on the financial performance by involving efficiency as mediation result shows that firm size has positive and significant effect of 0.37 with p-value $<0.001$; (b) the direct effect of the firm size on the financial performance without involving efficiency as mediation result shows that firm size has positive but not significant effect of 0.08 with p-value 0.26 ; (c) the effect of the firm size on the efficiency of the results shows that the firm size has negative and significant effect of -0.39 with $p$-value $<0.001$; and (d) the effect of efficiency on the financial performance result shows that efficiency has negative and significant effect of -0.94 with p-value $<0.001$. It is concluded that (c) and (d) have significant results while (b) the results are insignificant; the efficiency is said to be complete mediation (Solimun, 2010; Hair et al., 2010).

Tabel 2 - Hypothesis Testing and Path Coefficient

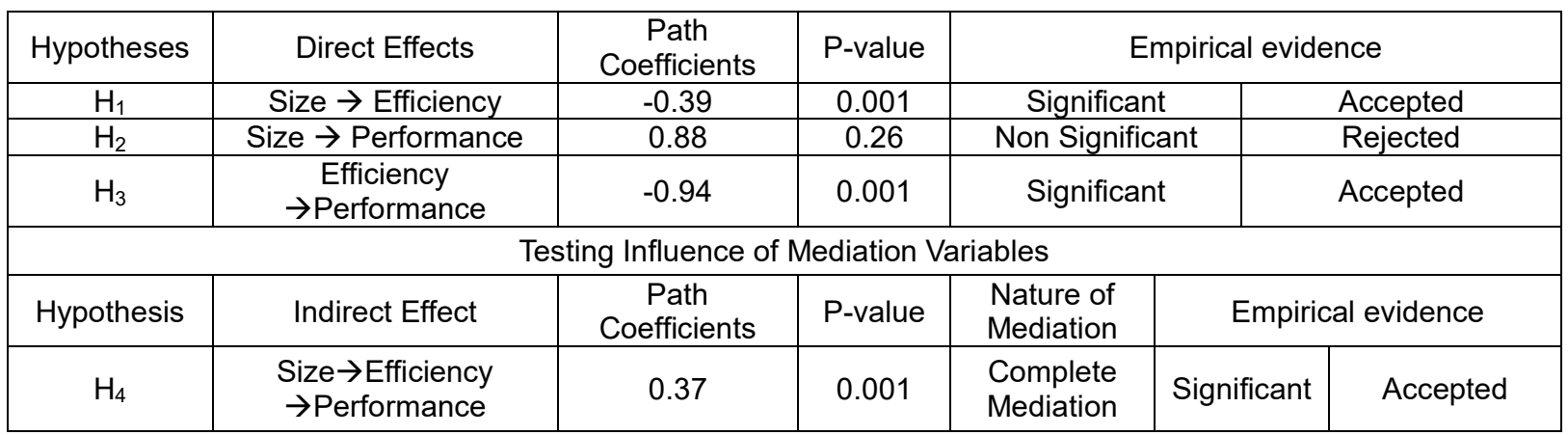

Description: Significant level at $1 \%$.

\section{DISCUSSION OF RESULTS}

The size of the firm shows the company's ability to generate profits with the aim of 
achieving economies of scale or able to improve the efficiency of banks that conduct $M \& A$ particularly through mergers in Indonesia. The test results show that firm size has a negative and significant effect on efficiency. This means that empirical evidence proves that a better implementation of the size of the merging banking company will increase the efficiency or the greater the size of the firm, the more efficiency increases.

Test results show that efficiency has a negative and significant effect on financial performance. This means that empirical evidence proves that a better implementation of the efficiency of the merged banks will improve the financial performance or the more efficient the company, the financial performance will increase.

The test results show that firm size has positive but not significant effect on financial performance. This means that empirical evidence proves that better implementation of the size of banking companies that do merger did not have an effect on the improvement of financial performance or the greater the size of the firm did not affect the financial performance.

The test results show that firm size has a positive and significant effect on financial performance mediated by efficiency. This means empirical evidence proves that a better implementation of the size of the combined company will improve the financial performance by involving the mediation of efficiency or the greater the size of the firm the higher the financial performance is mediated by efficiency. So the efficiency of the company plays an important role as a mediation relationship between firm size and financial performance. The role of efficiency mediation is the ability of firms to improve efficiency described as the ratio of operating costs to operating income. There is perfect mediation of efficiency that perfectly mediates the relationship between firm size and financial performance.

As explained in the previous section, the size of the merging banking company does not have a direct effect on financial performance, but it has indirect effect through the establishment of efficiency, meaning that the size of the firm will be able to create efficiency, then efficiency will affect the financial performance. Thus, one of the key factors in the creation of efficiency is determined by firm size, and efficiency plays an important role in mediating the relationship between firm size and financial performance.

The results of previous research on banking companies show that the size of the firm has a direct significant effect on financial performance, which means the larger the size of the firm, the financial performance will increase. This can happen because the larger the size of the firm, the greater the company's ability to improve the profitability of the company. This is in accordance with the results of previous research on banking companies that the size of the firm has a positive and significant influence on financial performance means the greater the size of the firm, the more financial performance (Alexiou \& Sofoklis, 2009; Gul et al., 2011; Naseem et al ., 2012; Doğan, 2013; Bilal et al., 2013 ; Dewi et al., 2016; Menicucci \& Paolucci, 2016).

The results of previous research that support the effect of firm size on efficiency is the research conducted by Casu and Molyneux (2003); Havrylchyk (2006); Altunbas et. Al. (2007); Yusniar (2011); Fathony (2012); Subandi and Gozali (2014) said that the size of the firm has a positive and significant effect on efficiency means that the larger the size of the firm, the more efficient. While that does not support the results of this study are the results of research conducted by Liao (2009) and Ong et al. (2011) said that the size of the firm has a negative and significant effect on efficiency means that the larger the size of the firm, the lower the efficiency. Even the results of research Girardone et al. (2004); Miah and Sharmeen (2015) say that firm size has no effect on efficiency.

While the results of previous studies that support the effect of efficiency on financial performance said that efficiency has a positive and significant effect on financial performance means more efficient, hence increasing the financial performance (Sukarno \& Syaichu, 2006; Alexiou \& Sofoklis, 2009; Dietrich \& Wanzenried, 2009; Sudiyatno \& Suroso, 2010; Prasanjaya \& Ramantha, 2013; Margaretha \& Zai, 2013; Purwoko \& Sudiyatno, 2013; Dewi et al., 2016). The results of research that does not support this research is the result of research conducted by Widati (2012); Sabir et al., 2013; Tan, 2013; Dawn et al. (2013) said that efficiency has no effect on financial performance. 
Thus it can be concluded that the size of a larger company then the financial performance increases through efficiency so that efficiency acts as a mediation to improve financial performance. The role of efficiency mediation is the ability of companies to improve efficiency is described as the ratio of operating costs to operating income means that increasing efficiency increases financial performance. So the size of the firm has a positive and significant effect on the financial performance mediated by the efficiency perfectly.

Theoretical and Managerial Implications. The results of this study are expected to provide insight on the concept of firm size associated with banking companies that do $M$ \& $A$. The concept of firm size starts from a small company can be seen from the small capital used and total assets owned. The indicator of firm size is the total assets of the total assets owned by the company (William, 2000; Menicucci \& Paolucci, 2016). Firm size is measured by the natural logarithm of total assets (Naiker et al., 2008) ie growth of company assets. The results of this study contradict the results of research Alexiou and Sofoklis (2009); Gul et al. (2011); Naseem et al. (2012); Doğan (2013); Bilal et al. (2013); Menicucci and Paolucci (2016); Dewi et al. (2016) states that the size of the firm affect the financial performance, but the results did not affect the financial performance of merged banks. This is because the factors that influence the implementation of firm size include problem loans, lack of capital and profitability decreased. The company wants the company to grow bigger, for that company to expand. The expansion is also intended to obtain economies of scale. The economic scale of a company is reflected in a decrease in operating costs (input) in line with an increase in its operating income (output). Companies get economies of scale when operating costs increase with lower levels of output. Approach the concept of firm size is done in an integrated manner to pay attention to the company's ability to improve efficiency and ultimately lead to improved financial performance.

The theoretical contribution of this research is expected to develop banking financial management science, especially banking merger by implementing firm size, efficiency and financial performance. The contribution of this study is also expected to develop conceptual and theoretical understanding of firm size in an effort to improve efficiency and financial performance. The results of this study bring additional evidence to investigate the model of structural relationships of firm size both directly and with the role of mediation. To know the effect of firm size on financial performance in banking industry that do merger in Indonesia based on banking finance management theory.

The practical contribution of this research is the managerial implications of the need to use firm size in an effort to improve the efficiency and effectiveness of banking operations, and to develop a framework through a firm size strategy with a banking efficiency management strategy. The results of this study provide knowledge and insight for managers about the implementation of the size of the firm in an integrated manner and not only fixated on the management of efficiency in order to achieve and maintain the efficiency and financial performance. The last is that the board of directors and managers of banking companies as leaders in the future should encourage the implementation of firm size in the banking industry that merges in Indonesia.

\section{CONCLUSION}

This study aims to contribute to the existing literature on banking mergers by investigating the effect of firm size on financial performance and the mediation role of efficiency. The results show that a good impementation of firm size can improve efficiency and financial performance. Enterprise size management has an important role in supporting the achievement of corporate size implementation objectives. This can provide a tangible contribution to improve the efficiency and financial performance of merging banks. Implementation of firm size is dominantly reflected in the company's total assets, while the dominant efficiency is reflected in the decrease in operating costs. Firm size is measured from the natural logarithm of total assets or Ln (total assets) reflects the growth rate of the firm's assets, while the efficiency is measured from the ratio of operating costs to operating income as a reflection of efficiency. 
Improved financial performance can not be separated from the implementation of a good firm size. The results of this study indicate that the effect of firm size on financial performance has not made a significant contribution to the merged banking companies. This result is because there are still problem loans, lack of capital and profitability decreased. Nonperforming loans resulted in the company having to provide sufficient reserves in accordance with the provisions of the banking authorities that caused huge losses to the company. Losses have an impact on company performance. Likewise, the limited capital strength of banks will limit the activity of banks to increase portfolio of productive assets and decline in profitability due to increased operating costs greater than the increase in revenue or due to declining operating income. This condition can be gradually improved so that the bank can expand optimally and have a healthy productive asset quality.

High efficiency can improve financial performance. The results of this study indicate that a better company in managing productive assets owned, a dominant factor in the company to create efficiency. This contributes significantly to the improvement of financial performance. Furthermore, the results of this study can prove the real role of efficiency, as a mediation relationship between the size of the firm and the financial performance of banks that merge in Indonesia. This means that a good implementation of firm size is not able to directly improve financial performance, but through the role of efficiency mediation, firm size can have a significant effect on financial performance.

Based on this, given the wide range of discussions and the large variations in changes in the corporate environment, this study has limitations in presenting the relationship of cross-sectional analysis. The data of this study were analyzed based on secondary data limited to cross-sectional analysis of relationships, due to the constantly changing business environment, to identify these changes required further research studies and to reexamine whether the relationships among variables analyzed in the study changed. Limited Object of research is the banks that do $M \& A$ in Indonesia. It thus limits the generalizability of the findings of this research to the banking industry in other countries. Therefore, further research in the future can develop the research model by adding other variables such as Capital Adequacy Ratio (CAR), Loan to Deposit Ratio (LDR), Debt to Equity Ratio (DER) and Non Performing Loan (NPL).

\section{REFERENCES}

1. Ali, K., Akhtar, M.F. and Ahmed, H.Z. 2011. Bank-Specific and Macroeconomic Indicators of Profitability - Empirical Evidence from the Commercial Banks of Pakistan. International Journal of Business and Social Science, Centre for Promoting Ideas, USA, Vol. 2 No. 6; April 2011.

2. Alexiou, C. and Sofoklis, V. 2009. Determinants Of Bank Profitability: Evidence From The Greek Banking Sector. Economic Annals, Volume LIV No. 182 / July - September 2009.

3. Altunbas, Y., Carbo, S., Gardener, E.P.M., and Molyneux, P. 2007. Examining the Relationships between Capital, Risk and Efficiency in European Banking. European Financial Management, Vol. 13, No. 1, 2007, 49-70.

4. Athanasoglou, P.P., Brissimis, S.N., Delis, M.D. 2006. Bank-specific, industry-specific and macroeconomic determinants of bank profitability. Journal of International Financial Markets, Institution and Money 18 (2008) 121-136.

5. Ayadi, R. and Pujals, G. 2005. "Banking Mergers and Acquisitions in The EU: Overview, Assessment and Prospect", SUERF - The European Money and Finance Forum, Vienna.

6. Bikker, J. A. and Bos, J. W. B. 2008. Bank Performance: A theoretical and empirical framework for the analysis of profitability, competition and efficiency. Routledge International Studies in Money and Banking, London \& New York.

7. Bilal, M., Saeed, A., Gull, A.A and Akram, T. 2013. Influence of Bank Specific and Macroeconomic Factors on Profitability of Commercial Banks: A Case Study of Pakistan. Research Journal of Finance and Accounting, Vol.4, No.2, 2013.

8. Campa, J.M. and Hernando, I. 2006. "M \& As performance in the European financial industry" Journal of Banking \& Finance 30 (2006) 3367-3392. 
9. Casu, B. and Molyneux, P. 2003. A comparative study of efficiency in European banking, Applied Economics, 35:17, 1865-1876.

10. Christian, C., Moffitt, J.S. and Suberly, L.A. 2008. Fundamental analysis for evaluating bank performance: what variable provide the greatest insight into future earning? Jurnal Bank Accounting Financial, 22: 17-24.

11. Dewi, F.S., Arifati, R. and Andini, R. 2016. Analysis of effect of CAR, ROA, LDR, LDR, Company Size, NPL and GCG to Bank Profitability (Case Study on Banking Companies Listed in IDX period 2010-2013), Journal Of Accounting, Volume 2 No.2 Maret 2016.

12. Dendawijaya, Lukman. 2005. Banking Management. Issue 2, Ghalia Publisher Indonesia, Jakarta.

13. Dietrich and Wanzenried. 2009. What Determines the Profitability of Commercial Banks? New Evidence from Switzerland, The Annual Conference of the Swiss Society for Financial Market Research.

14. DePamphilis, D. 2011. Mergers and Acquisitions Basics: all you need to know, Academic Press is an imprint of Elsevier, Burlington, MA.

15. Doğan, M. 2013. Does Firm Size Affect The Firm Profitability? Evidence from Turkey. Research Journal of Finance and Accounting, Bayat Vocational School, Afyon Kocatepe University, Bayat Afyonkarahisar,Turkey, Vol.4, No.4, 2013.

16. Epstein, M.J. 2005. "The determinants and evaluation of merger success", Business Horizons (2005) 48, 37- 46.

17. Fathony, M. 2015. Estimates and Factors Affecting the Efficiency of Domestic and Foreign Banks in Indonesia. Journal of Finance and Banking, Vol.16, May 2, 2012, p. 223-237.

18. Fajar, A., Hedwigis, E.R and Tri, P.E.K.P. 2013. Analysis of Bank's internal and external factors affecting Profitability of Commercial Banks in Indonesia. Journal of Management and Business Review, Vol.10, No.1, January 2013: 63-67.

19. Ghozali, I. and Latan. 2014. Partial Least Squares - Concepts of Methods and Applications, using WarpPLS 4.0 Program, Second Edition, Diponegoro University Publishing Agency, Semarang.

20. Girardone, C., Molyneux, Gardener, E.P.M. 2004. Analysing the determinants of bank efficiency: the case of Italian banks, Applied Economics, 36:3, 215-227,

21. Gul, S., Irshad, F. and Zaman, K. 2011. Factors Affecting Bank Profitability In Pakistan. The Romanian Economic Journal, Year XIV, no. 39, March 2011.

22. Hair, J. F., Black, W, C., Babin, B. J., and Anderson, R. E. 2010. Multivariate Data Analysis, Seventh Edition, Pearson Education.

23. Havrylchyk, O. 2006. Efficiency of the Polish banking industry: Foreign versus domestic banks. Journal of Banking \& Finance 30 (2006) 1975-1996.

24. Javaid, S., Anwar, J., Zaman, K. and Gafoor, A. 2011. Internal Factor Analysis Of Bank Profitability. Mediterranean Journal Of Social Sciences, Vol. 2, No. 1, January 2011.

25. Kuncoro, M. and Suhardjono. 2002. Banking Management: Theory and Applications, July, Issue 1, BPFE UGM, Yogjakarta.

26. Kumar, K.B. and R.G. Rajan and L. Zingales, (2001). What determines firm size?, Working paper, University of Chicago.

27. Lelissa, T.B. 2014. The Determinants of Ethiopian Commercial Banks Performance, European Journal of Business and Management, Vol.6, No.14, 2014.

28. Liao, C. 2009. Efficiency and productivity change in the banking industry in Taiwan: domestic versus foreign banks. Banks and Bank Systems, Volume 4, Issue 4, 2009.

29. Margaretha, F. and Zai, M.P. 2013. Factors Affecting Indonesia Banking Financial Performance. Journal of Business and Accounting, Trisakti University, Vol. 15, No.2, December 2013, pp. 133-141.

30. Mathuva, D.M, 2009. Capital Adequacy, cost income Ratio and the Performance of Commercial Bank: The Kenyan Scenario. The International Journal of Applied Economic and Finance 3 (2): 35-47, 2009. 
31. Menicucci, E. and Paolucci, G. 2016. The determinants of bank profitability: empirical evidence from European banking sector. Journal of Financial Reporting and Accounting, Vol. 14 Iss 1 pp. $86-115$.

32. Miah, M.D \& Sharmeen,K. 2015. Relationship between capital, risk and efficiency: A comparative study between Islamic and conventional banks of Bangladesh. International Journal of Islamic and Middle Eastern Finance and Management Vol. 8 No. 2, 2015 pp. 203-221.

33. Mulyaningsih dan Daly. 2011. "Competitive Conditions in Banking Industry: An empirical Analysis of the Consolidation, Competition and Concentration in the Indonesia Banking Industry between 2001 and 2009", Economic Bulletin, Monetary and Banking, Oktober 2011.

34. Naiker, Vic, Farshid Navissi, VG Sridharan. 2008. "The Agency Cost Effects of Unionization on Firm Value", Journal of Management Accounting Research, Vol. 20, pp. 133-152.

35. Naseem, I., Saleem, A., Shah, S.Q. and Shah, A.A. 2012. The Profitability of Banking Sector in Pakistan: An Empirical Analysis from 2006-2010. Science Series Data Report, Vol 4, No. 2;Feb 2012.

36. Ong, T.S., Lim, Y.T and Teh, B.H. 2011. A comparison on Efficiency of Domestic and Foreign Banks in Malaysia: A DEA Approach. Business Management Dynamics Vol.1, No.4, Oct 2011, pp.33-49.

37. Otoritas Jasa Keuangan. 2015. Indonesian Banking Statistics, Agustus 2015.

38. Pasiouras, F. \& Kosmidou, K. 2007. Factors influencing the profitability of domestic and foreign commercial banks in the European Union. Research in International Business and Finance 21 (2007) 222-237.

39. Prasanjaya, A.A. and Ramantha, I.W. 2013. Influence Analysis of CAR Ratio, BOPO, LDR and Company Size on Profitability of Banks listed on IDX. E-Journal of Accounting Udayana University 4.1 (2013): 230-245.

40. Putri, V.P. and Lukviarman, N. 2008. "Commercial Bank Performance Measurement with Efficiency Approach": Studies on Go-Public banking in Indonesia, Journal of Accounting Auditing Indonesia volume 12 No.1, June 2008: 37-52.

41. Purwoko, D. and Sudiyatno, B. 2013. Factors Affecting Bank Performance (Empirical Study on Banking Industry In Indonesia Stock Exchange). Journal of Business and Economics (JBE), March 2013, p. 25 - 39, Vol. 20, No. 125.

42. Sabir, M.M., Ali, M. and Habbe, A.H. 2012. Influence of Bank Health Ratios on Financial Performance of Sharia and Conventional Banks In Indonesia. Journal of Analysis, June 2012, Vol.1 No.1: 79 - 86.

43. Said and Tumin. 2011. Performance and Financial Ratios of Commercial Banks in Malaysia and China, International Review of Business Research Papers. Vol. 7. No. 2. March 2011. Pp. 157-169.

44. Solimun, 2010. Structural Equations Modeling Approach PLS Equipped Variable Moderator Discussion. Statistics Program FMIPA, Doctoral Program of Management Science FE Universitas Brawijaya.

45. Solimun, 2010. Pemodelan Persamaan Struktural Pendekatan PLS Dilengkapi Pembahasan Variabel Moderator. Program Studi Statistika FMIPA, Program Doktor IImu Manajemen FE Universitas Brawijaya.

46. Subandi and Gozali, I. 2014. An Efficiency Determinant of Banking Industry in Indonesia. Research Journal of Finance and Accounting, Vol.5, No.3, 2014.

47. Sudiyatno, B. and Suroso, J. 2010. Analysis of the Influence of Third Party Funds, BOPO, CAR and LDR on Financial Performance in Public Banking Sector In Indonesia Stock Exchange (IDX) (Period 2005-2008). The Dynamics of Finance and Banking, May 2010, Hal: 125 - 137.

48. Sufian, F. and Habibullah, M. S. 2009. Determinants of bank profitability in a developing economy: empirical evidence from Bangladesh, Journal of Business Economics and Management, 2009, 10(3): 207-217. 
49. Sufian, F. and Habibullah, M.S. 2010. Assessing the Impact of Financial Crisis on Bank Performance: Empirical Evidence from Indonesia, ASEAN Economic Bulletin Vol. 27, No. 3 (2010), pp. 245-62.

50. Sukarno, K. W. and Syaichu, M. 2006. Analysis of Factors Affecting the Performance of Commercial Banks In Indonesia. Journal of Management \& Organization Studies, Volume 3, Number 2, July, Year 2006, Page 46, Diponegoro University.

51. Sutawijaya, A. and Lestari, E. P. 2009. Efficiency of Indonesian Banking Techniques Post Economic Crisis: An Empirical Study of the Application of DEA Model, Journal of Development Economics, Vol. 10, No.1, June 2009, p. 49-67.

52. Tan, S.E. 2013. Influence of NIM, BOPO, LDR, NPL \& CAR Against ROA of International Bank and National Bank Go Public Period 2007 - 2011. Journal of Management Dynamics Vol. 1 July 3 - September 2013.

53. Yusniar, M.W. 2011. Analysis of Banking Industry Efficiency in Indonesia with Data Envelopment Analysis (DEA) Approach and Its Affecting Factors. Journal of Management \& Business Vol. 1 March 2, 2011.

54. Widati, L.W. 2013. Effect Analysis of Camel on Corporate Banking Performance Go Public. Dynamics of Accounting, Finance and Banking, November 2012, Page: 105 - 119 Vol. 1, No. 2.

55. William, S.M. 2000. "Is intellectual capital performance and disclosure related?", Journal of Intellectual Capital, Vol. 2. No. 3, pp. 192-203. 